Delfim F. Leão

\title{
5 Alexandria, Diaspora, Politeuma and Patrioi Nomoi: The Sharing and Hiding of Jewish Identity
}

\subsection{Introduction}

During the Hellenistic period, most of the former Greek poleis continued to exist, at least as urban spaces, although without the autonomy and liberty of movement that they had enjoyed during the Archaic and Classic periods, especially in terms of foreign policy. ${ }^{1}$ Because the essence of the Hellenistic state depended on the monarch and on those working more directly with him, the structure of the polis ended up being a strange body within this new reality. Even so, it could not simply be eliminated, because of the symbolic importance it had in the past history of Greece. The poleis managed thereby to keep the essence of the constitutional apparatus of the past (popular assembly, council, courts, annually elected magistrates), but were now dependent on the will of the king, whose orders had to be obeyed, whether transmitted by letter, by royal regulation (diagramma) or by royal ordinance (prostagma). Formally, the façade of autonomy was therefore kept, as long as the decrees of the polis were moulded according to the instructions of the monarch, which were thus turned into binding laws. Up to a certain point, this situation constituted a fiction tacitly accepted by both parties, because both could extract benefits from it. ${ }^{2}$

Another feature distinctive of the Hellenistic period and of the strategy adopted by Alexander was the founding of new cities, sometimes with a demographic concentration that would have been unthinkable to the classic poleis.

1 This work is partially an adapted and expanded version of Delfim F. Leão, "Identity and Cosmopolitanism: The Jewish 'Politeuma' of Alexandria," in Alexandrea ad Aegyptum: The Legacy of Multiculturalism in Antiquity, ed. Rogério Sousa, Maria C. Fialho, Mona Haggag, and Nuno S. Rodrigues (Porto: Afrontamento, 2013), 122-33. I wish to thank Manuel Tröster, who read an earlier version of this paper and whose comments helped me to improve it, especially at the linguistic level. This research was developed under the project UID/ELT/00196/2013, funded by the Portuguese FCT - Foundation for Science and Technology.

2 At any rate, the payment of a tribute and the acceptance of the presence of royal garrisons, among other charges supported by each individual polis, were an unequivocal sign of their dependence on the power of the sovereign. 
The most emblematic of those new establishments was certainly Alexandria, ${ }^{3} \mathrm{a}$ AU: We have shortened the running head. Please check city that would substitute Memphis as the capital of Egypt, under the Ptolemies, the dynasty initiated by the former general of Alexander, who quickly understood how unrealistic it was simply to try to replace the former ruler by another person. Instead of that, he chose to reinforce the stability of the reign of Egypt, an objective that went in accord with the preoccupation of legitimating his power as sovereign. ${ }^{4}$

Identical motivation may explain, at least in part, the construction of the two most emblematic monuments of the new capital: the Museum and the Library. In fact, they both represented, even in antiquity, a vivid illustration of the cosmopolitan spirit of the new Hellenistic cities. ${ }^{5}$ Besides that, in the case of the Ptolemies those monuments contributed as well to the purpose of reinforcing the connection with Alexander and of legitimating the authority of a Greek (and hence foreign) matrix in a cultural context as exuberant as that of ancient Egypt.

Despite the importance of those emblematic constructions, the city of Alexandria constituted also a notable ethnic mosaic, where three communities were particularly important: the native Egyptians, the Macedonians and Greeks in general (culturally and politically dominant), and the Jews. Even if it is correct to state that the authority of the pharaoh worked as a coalescing force, fundamental to keep the whole bulk together, there was nevertheless a high risk of disaggregation (or al least of conflict), especially on the part of those who were more ardent in keeping their religious and cultural roots, as happened with the Jews. It is therefore the aim of this paper to discuss, in the next section, the way the cosmopolitanism characteristic of the Hellenistic period (and of Alexandria in particular) managed to deal with the demands of a strong and deeply rooted awareness of Jewish identity.

3 In antiquity, almost twenty cities were founded with the name Alexandria. For a collection of the sources dealing with the cities founded by Alexander, see Waldemar Heckel and John C. Yardley, Alexander the Great: Historical Sources in Translation (Malden: Blackwell, 2004), 303-10. 4 On the strategy adopted by Ptolemy to legitimate his power, see Andrew Erskine, "Culture and Power in Ptolemaic Egypt: The Museum and Library of Alexandria," Greece and Rome 42 (1995): 38-48.

5 Their creation is generally understood as an expression of the Peripatetic influence on this golden period for science, but it also matches a long-lasting tradition of cultural sponsorship, deeply rooted already in the tyrannies of the Archaic and Classical periods, which the new monarchs intended to cultivate as well. See Victor Parker "Tyrannos: The Semantics of a Political Concept from Archilochus to Aristotle," Hermes 126 (1998): 145-72; Delfim F. Leão, “The Tyrannos as a Sophos in the Septem Sapientium Convivium," in Symposion and Philanthropia in Plutarch, ed. José Ribeiro Ferreira, Delfim Leão, Manuel Tröster, and Paula Barata Dias (Coimbra: Imprensa da Universidade, 2009), 511-21, at 518-19. 


\subsection{Greeks and Jews}

The trail of contacts between the Greek world and the Jews goes back to a very distant time in the past, as can be inferred from Hebrew names (as Japheth and Javan) reminiscent of Greek mythical names (Iapetos and Ion), and from the fact that king David himself employed, in a period as distant as the tenth century, Greek mercenaries from Crete. On the other side, remains of pottery found in Samaria suggest the existence of commercial contacts with Greece as early as the eighth century. The traditional Athenian emblem of the owl was discovered on Jewish coins minted in the fifth century and, during the Persian invasion, Jewish mercenaries were among the Persian troops that invaded Greece, in 480 BCE, under the orders of Xerxes. ${ }^{6}$ One of the earliest significant allusions to the Jews, in Greek literature, occurs in a short reference in the Histories of Herodotus (2.104.2-3), concerning the circumcision, a practice that the Syrians of Palestine (i.e. the Jews) adopted from the Egyptians. ${ }^{7}$ According to Josephus (Ag. Ap. 1.176-182), Clearchus of Soli, a former pupil of Aristotle, related in his first book On Sleep that the master had a meeting with a Jew in Asia Minor. The story is usually considered to be apocryphal, but the fact that the Peripatetic Clearchus found the anecdote worthy of record is an indicator of the high opinion held on the Jews (as well as on the Indians) as a people naturally disposed to philosophical reasoning. An approach identically positive is made by Theophrastus, whose testimony (quoted by Porphyry, Abst. 2.26) has the undeniable merit of being the earliest source, outside the Bible, to describe the Jewish sacrifices. ${ }^{8}$ Among those earliest accounts on Jews made by non-Jews, the largest testimony derives from the work History of Egypt written by Hecataeus of Abdera, which is preserved in a long passage quoted by Diodorus of Sicily (Bibl. Hist. 40.3). Even if this work contains certain mistakes (as stating that Moses founded Jerusalem and established the sacred temple) and manifests some criticism towards the zealous character of the Jews, as a social characteristic deriving from the harsh experience of exile

6 Cf. Flavius Josephus, Ag. Ap. 1.172-173, who derives this information from a Greek poet named Choerilus. See Louis H. Feldman and Meyer Reinhold, Jewish Life and Thought among Greeks and Romans: Primary Readings (Edinburgh: T\&T Clark, 1996), 1.

7 For other parallelisms between the Semitic world and Greek literature, from the Homeric poems down to Xenophon, see the detailed systematization of Nuno S. Rodrigues, "Um olhar a Oriente: Imagens do mundo semítico na literatura grega, dos Poemas Homéricos a Xenofonte," in Génese e consolidação da ideia de Europa, Vol. I: de Homero ao fim da Época Clássica, ed. Maria do Céu Fialho, Maria de Fátima Silva, and Maria Helena da Rocha Pereira (Coimbra: Imprensa da Universidade, 2005), 335-65.

8 Even if he also records several mistakes, like stating that sacrifices were made during the night or that humans were used as sacrificial victims. 
(40.3.4), Hecataeus presents nonetheless a quite positive image of the Jews, with whom he might have been in direct contact by the time he visited Egypt.

With the reference to Hecataeus of Abdera (who lived c. 360-290 BCE), one reaches a period comprised between the campaigns of Alexander and the beginnings of the dynasty of the Ptolemies, an epoch that shall open a new and gleaming chapter in the history of the Jews, especially in what concerns their establishment in Egypt. Josephus (Ag. Ap. 1.186-204) ascribes to this same Hecataeus a treaty On the Jews, but its author is, most probably, a Jew that might have composed the work around the middle of the second century. ${ }^{9}$ Despite these limitations, one of the passages of Pseudo-Hecataeus quoted by Josephus is quite illustrative of the importance attributed to the respect of traditional regulations among Jews - a feature that Alexander was wise enough to respect, similarly to what he did with other conquered populations, like the Persians. It is therefore pertinent to evoke this episode as an introduction to the question of the privileges that might have been received by the Jews who decided to move to Alexandria $^{10}$ :

\begin{abstract}
Then Hecataeus indicates in turn our attitude toward the laws (nomoi), that we choose to suffer anything rather than transgress them, and consider this to be noble. For this reason, he says, though they are verbally abused by their neighbors and by all those who arrive from abroad, as well as being insolently treated on a regular basis by the Persian kings and satraps, they cannot be shifted from their conviction; on the contrary, defenseless they face on behalf of these both tortures and the most terrible of all deaths rather than deny their ancestral ways (ta patria). He also provides several evidences of this strong-mindedness in relation to the laws (nomoi). He says that when Alexander was on one occasion in Babylon and had decided to clear the temple of Bel which had collapsed, he ordered all his soldiers alike to transport the soil; only the Judeans did not comply, but endured severe beating and paid heavy fines, until the king pardoned them and granted them an amnesty. (Josephus, Ag. Ap. 1.190-192)
\end{abstract}

The presence of Jewish troops serving under Alexander does not constitute a major surprise, because, as discussed above, it was possible as early as the fifth century to find Jewish mercenaries in the Persian army. ${ }^{11}$ On the other hand, the

9 For more details on the "discovery" of the Jews by Greek authors, see Feldman and Reinhold, Jewish Life and Thought among Greeks and Romans, 1-14, at 10, in what respects the case of Pseudo-Hecataeus analysed here.

10 The translation is taken from Steve Mason, Josephus: Against Apion, Translation and Commentary (Leiden: Brill, 2007), 110-12. The Greek words transcribed in brackets are my addition. The same applies to other passages quoted in translation throughout the paper.

11 Martin Hengel, "The Interpenetration of Judaism and Hellenism in the pre-Maccabean Period," in The Cambridge History of Judaism, ed. William D. Davies and Louis Finkelstein (Cambridge: Cambridge University Press, 1989), 167-228, at 187 and n. 1, says that there is no reason to doubt that Jewish mercenaries served under Alexander, although he considers unhistorical the 
idea that the Macedonian leader might have shown indulgence respecting the interdictions dictated by Jewish laws (even facing the risk of some loss of authority $)^{\mathbf{1 2}}$ finds a possible parallel in the way he knew to respect former enemies, either because he was convinced that this was the best way of acting or by mere political pragmatism. ${ }^{13}$ Thus, besides not being wholly improbable from a historical perspective, this detail is in accord with the tradition that tended to present Alexander as a great benefactor of Jewish identity, to the point of suggesting that this support may have been influenced by divine intervention.

This is the case of the first visit of Alexander to Jerusalem (in 332 BCE), which was preceded by moments of great tension, because the high priest had decided, in a first instance, to remain faithful to Darius, a choice that made the Macedonians march against Jerusalem. The vivid memory of this episode was preserved in Josephus's Jewish Antiquities (Ant. 11.304-346), in terms whose historicity is, to say the least, highly suspect. Actually, the epiphany of Alexander in Jerusalem has too many points of contact with another experience of divine inspiration - a fact that cannot be ruled out as simple coincidence - lived during the first part of the year 331: the famous pilgrimage of the Macedonian king to the sanctuary of Amon, in the oasis of Siwah (Libya), undertaken in a time when he had already chosen the place where the new capital of Egypt was to be established. ${ }^{14}$ Several details adduced when Alexander visits the temple of Jerusalem - like bringing the Book of Daniel before him (a book which was in reality written only around 164 BCE), evoking the prophecy that a Greek would overcome the Persian empire - strongly suggest that the episode reflects a later Jewish tradition, in which some usual signs of legendary amplification can be detected in what respects the deeds

tradition stating that the Macedonian monarch gave isopoliteia to the Judean soldiers that decided to establish themselves in Alexandria. Aryeh Kasher, "The Jewish Politeuma in Alexandria: A Pattern of Jewish Communal Life in the Greco-Roman Diaspora," in Homelands and Diasporas: Greeks, Jews and Their Migrations, ed. Minna Rozen (London: I.B. Tauris, 2008), 109-25, at 122, sustains on the contrary that the Jewish politeuma of Alexandria had "political equality" (isopoliteia) enabling its members to "organize independently (of the polis) and maintain their own autonomous legal and religious establishments."

12 Mason, Josephus: Against Apion, 112 n. 650, comments that the punishment of those disobeying soldiers "seems unnaturally light."

13 On the way, Alexander's behaviour evolved from the image of a leader of a pan-Hellenic colligation against the Barbarians into a strategy of favouring the inclusion of the defeated into the new budding order, see Delfim F. Leão, "Alexandre Magno: da estratégia pan-helénica ao cosmopolitismo," in Atti del convegno internazionale di studi "Plutarco e l'età ellenistica," ed. Angelo Casanova (Florence: Università degli Studi di Firenze, 2005), 23-37.

14 For an analysis of Josephus's report, by comparing aspects of the expedition to Jerusalem with the visit to the sanctuary of Amon, see Joseph Mélèze Modrzejewski, The Jews of Egypt: From Rameses II to Emperor Hadrian (Skokie/Ill.: Varda Books, 1995), 50-55. 
of the Macedonian leader. Nonetheless, it is still pertinent for the objectives of this analysis to recall the final part of the narrative, where the putative privileges granted by Alexander to the Jews are mentioned ${ }^{15}$ :

And, when the book of Daniel was shown to him, in which he had declared that one of the Greeks would destroy the empire of the Persians, he believed himself to be the one indicated; and in his joy he dismissed the multitude for the time being, but on the following day he summoned them again and told them to ask for any gifts which they might desire. When the high priest asked that they might observe their country's laws (patrioi nomoi) and in the seventh year be exempt from tribute, he granted all this. Then they begged that he would permit the Jews in Babylon and Media also to have their own laws (idioi nomoi), and he gladly promised to do as they asked. And, when he said to the people that if any wished to join his army while still adhering to the customs of their country (ethe patria), he was ready to take them, many eagerly accepted service with him. (Josephus, Ant. 11.337-339)

Leaving aside the question of the highly suspect historicity of this report, which moves back to the time of Alexander decisions that were, in fact, taken much later, ${ }^{16}$ the essence of the political and ideological meaning of the measures here mentioned may nevertheless be valid. In reality, from a political perspective, this report shows that Judea was able to keep, throughout the Hellenistic period, a position comparable to the one it had during the Persian domination: the capacity to act as an ethnic and religious entity, organized around the priesthood power, whose centre was the sacred temple at Jerusalem. From an ideological viewpoint, the account illustrates the bases for the interrelations that were to be established between the Hellenistic sovereigns and the Jews: the first would distribute benefits and accept to respect the Mosaic law, while the latter would guarantee loyalty to the monarch and the readiness to fight under his command. There was however an important evolution concerning the inner legal nature of the Torah: in the past, it worked for the Jews as a law issued by the central power, binding by itself, but now it was presented as the "ancestral law" (patrios nomos) of the Jews, whose validity had to be confirmed by the new rulers. This way the Torah ended up by becoming closer to the juridical statute of the patrioi nomoi used by the Greeks of the Asian cities freed by Alexander from Persian rule, thus finding a balanced and ingenious mode of keeping the essence of deeply rooted religious traditions in a new political and social order.

15 The translation is taken from Ralph Marcus, Flavius Josephus: Jewish Antiquities, Books IX-XI (London: Loeb, 1958), 477-79.

16 Mélèze Modrzejewski, The Jews of Egypt, 55, says that Josephus is attributing to Alexander a much later event, thus simply "anticipating by some 130 years the step actually taken by Antiochus III about 200 BCE, when he established the status of Jerusalem in the Seleucid empire." 


\subsection{A Jewish Politeuma in Alexandria?}

The above-mentioned possible parallelism between the legal situation of the Jews and that of the Greeks is a question that demands further inquiry, taking as reference the Jewish politeuma of Alexandria, whose existence, if historically accepted, would represent an elucidative example of the way the Jews from the Diaspora could organize themselves into stable communities, from a social, political and legal standpoint. Although the existence of this politeuma has traditionally been accepted, some scholars actually deny it. ${ }^{17}$ In fact, despite its prominence, there are no definite proofs that it really existed, even if that is very likely. In a review of communities organized as politeumata - representing a specific kind of association, especially during the Hellenistic period - , Patrick Sänger ${ }^{18}$ convincingly argues that the term politeuma has several meanings and covers a very wide range of realities, such as defining simply a 'political act' of any kind up to the very

17 For a conspectus of the main lines of the debate, see Kasher, "The Jewish Politeuma in Alexandria," 109-12. See also, Constantine Zuckerman, "Hellenistic politeumata and the Jews: A Reconsideration,” Scripta Classica Israelica 8/9 (1985-1988): 171-85; Sylvie Honigman, The Septuagint and Homeric Scholarship in Alexandria: A Study in the Narrative of The Letter of Aristeas (London: Routledge, 2003), 98-118; Patrick Sänger, “Die Jurisdiktion der jüdischen Gemeinde von Herakleopolis: Normal- oder Sonderfall im hellenistischen Ägypten?” in Symposion 2015: Vorträge zur griechischen und hellenistischen Rechtsgeschichte, ed. Delfim F. Leão and Gerhard Thür (Vienna: Verlag der Österreichischen Akademie der Wissenschaften, 2016), 213-32, at 214-18. 18 Patrick Sänger, "The Politeuma in the Hellenistic World (Third to First Century B.C.): A Form of Organisation to Integrate Minorities," in Migration und Integration-wissenschaftliche Perspektiven aus Österreich Jb 2, ed. Julia Dahlvik, Christoph Reinprecht, and Wiebke Sievers (Vienna: University Press, 2013), 51-68. The subject is taken up again by him, in a paper written in German that explores the same basic argument, although extending and concretizing the discussion around the meaning of the term politeuma: Patrick Sänger, "Das politeuma in der hellenistischen Staatenwelt: Eine Organisationsform zur Systemintegration von Minderheiten," in Minderheiten und Migration in der griechisch-römischen Welt: politische, rechtliche, religiöse und kulturelle Aspekte, ed. Patrick Sänger, Studien zur historischen Migrationsforschung 31 (Paderborn: Ferdinand Schöningh, 2016), 25-45. For the questions dealing with the concept of politeuma in general, see Walter Ruppel, "Politeuma: Bedeutungsgeschichte eines staatsrechtlichen Terminus," Philologus 82 (1927): 268-312 and 433-54; Arnaldo Biscardi, "Polis, politeia, politeuma," in Atti del XVII Congresso Internazionale di Papirologia (Naples: Centro Internazionale per lo Studio dei Papiri Ercolanesi, 1984), 1201-15; Gert Lüderitz, “What is the politeuma?” in Studies in Early Jewish Epigraphy, ed. Jan Willem van Henten and Pieter W. van der Horst, Arbeiten zur Geschichte des antiken Judentums und des Urchristentums 21 (Leiden: Brill, 1994), 183-225; Mogens Herman Hansen, "Polis, Politeuma and Politeia: A Note on Arist. Pol. 1278b6-14," in From Political Architecture to Stephanus Byzantius. Sources for the Ancient Greek Polis, ed. David Whitehead (Stuttgart: Franz Steiner, 1994), 91-8; Delfim F. Leão, “Politeuma in Plutarch,” Synthesis 23 (2016): e007. Released November 2016: http://www.synthesis.fahce.unlp.edu.ar/article/view/SYNe007. 
specific and technical designation of ethnically categorized communities with a military background that can be described as semi-autonomous administrative units, as they existed in several towns or districts of Ptolemaic Egypt ${ }^{19}$ :

The word politeuma is frequently used in the Greek language, and has a wide spectrum of meanings. It can, for instance, refer to a 'political act' or appear as a term for 'government', 'citizenry' or 'state'. As a technical term politeuma can, in the context of a Greek city-state or polis, also refer to the political leading class of citizens as a sovereign body with specific rights. Therefore, in an oligarchic constitution the word refers to a section of the citizenry; in a democratic one to the entire citizenry. However, the word, as a technical term, is not just restricted to the political organisation of a classical Greek polis, but can also be applied to name a specific and organised group of persons within an urban area. In this context we are dealing, apart from one exception (namely a politeuma of soldiers in Alexandria [...]), with minorities whose ethnic designation is pointing to a migrant background. The members of such a politeuma were concentrated in a certain district of a town, which was initially foreign to them and where they lived as an ethnic community.

From a legal and constitutional perspective, the most complex and also most interesting use of the term politeuma is the one mentioned last, which designates a reality that could be found during the Hellenistic period and that seems to be specific to the strategic political planning of the Ptolemies, as an ingenious way of promoting in the regions under their control migrant groups, probably military in their origin and usually sharing the same ethnic roots, by allowing them to govern themselves as administrative units. In fact, eight ethnic politeumata have been identified for this period, all of them in areas controlled by the Ptolemies. ${ }^{20}$ Two of them have attracted much attention, both consisting of Jewish groups: those of Herakleopolis and of Berenike. ${ }^{21}$ The case of Herakleopolis in Middle Egypt is of capital importance, because a group of twenty papyri (P.Polit. Iud., dated between 144/43 and 133/32 BCE) was found there and made a determinant contribution to the understanding of the administrative function of the institution of the politeuma. For they show that the officials who governed the Jewish politeuma dealt, on the one hand, with disputes that were internal (and sometimes also external) to the community associated to the politeuma and, on the other hand, they also provide a good impression of the range of legal issues

19 Sänger, "The Politeuma in the Hellenistic World (Third to First Century B.C.)," 52. See also Sänger, "Das politeuma in der hellenistischen Staatenwelt," 35-8.

20 This is probably true even for the politeumata at Sidon. See Sänger, "The Politeuma in the Hellenistic World (Third to First Century B.C.),” 53-7 and 61.

21 Unlike the possible (and probable) Jewish politeuma of Alexandria, attested only by the so called "Letter of Aristeas," later referred to in this analysis, the politeumata of Herakleopolis and of Berenike are corroborated by independent documentation. 
these officials covered. The competences they had in the field of justice are comparable to those of Ptolemaic officials, a feature that seems to indicate that politeumata resembled semi-autonomous communities whose internal structure had obtained a public dimension, a transformation that was certainly due to a governmental decision. It is therefore quite significant that the institution of politeumata by the Ptolemies allowed them to attract and integrate migrant groups who were useful to their kingdom (especially for the army), incorporating them in the upper levels of the population, by giving them a fixed place in the administration of Ptolemaic Egypt. ${ }^{22}$

It is now time to focus again on the case of Alexandria. According to Pseudo-Hecataeus, ${ }^{23}$ not long after the battle of Gaza (312), the group of Jews who came to Egypt following the Macedonian conquest brought with them the Torah. Ezekias, the high priest who accompanied them from Judea, gathered a group of friends, possibly during the Sabbath, and read them the whole text, in Hebrew. Still according to Pseudo-Hecataeus, "he had their settlement (katoikesis) and the constitution written (politeia gegrammene)."24 The passage is awkward and ambivalent, because the context does not make clear whether the terms katoikesis and politeia should be understood as being applied to the past history of the Jews or to the very moment when this group established itself in Alexandria. ${ }^{25}$ Independent from the way this passage is interpreted, it remains a fact that the Jewish community felt very soon the need of having a Greek translation of the Torah, due perhaps to the fact that the process of Hellenization had been so quick

22 See Zuckerman, "Hellenistic Politeumata and the Jews"; Sänger, "The Politeuma in the Hellenistic World (Third to First Century B.C.)," 63-6; Sänger, "Das politeuma in der hellenistischen Staatenwelt," 41-4.

23 Quoted by Josephus, Ag. Ap. 1.186-189.

24 Josephus, Ag. Ap. 1.189. Translated by Mason, Josephus: Against Apion, 110.

25 Hengel, "The Interpenetration of Judaism and Hellenism in the pre-Maccabean Period," 192-3, is also ambivalent in the way he interprets this politeia gegrammene, which he tends to identify with a royal decree allowing the Jews to establish themselves in Alexandria with a special statute of ethnic minority. Harald Hegermann, "The Diaspora in the Hellenistic Age," in The Cambridge History of Judaism, ed. William D. Davies and Louis Finkelstein (Cambridge: Cambridge University Press, 1989), 115-67, at 160, states that the passage expressly mentions "a short royal decree, the contents of which would be comparable to the letter from Antiochus III to Zeuxis." However, the suggestion that the text was read from the (Hebrew) original may imply, on the contrary, that it was the Torah and that the politeia in question was the constitution of the Judean nation. On the other hand, the idea that Ezekias "had been closely in touch with us" (synethes hemin genomenos) may be an indication that the high priest was acquainted with the Greeks and with their habits. On the interpretation of this crooked passage and on its connection to the translation of the Septuagint, see also Mélèze Modrzejewski, The Jews of Egypt, 99-104; Mason, Josephus: Against Apion, 110 n. 636. 
that, a few decades after their establishment in Alexandria, most of the Jews were no longer able to understand Hebrew. The first version of the Torah in Greek is the famous translation by the Septuagint, and this is not the time to discuss thoroughly in what conditions it may have been executed. For the purposes of the present paper it is enough to recall two possible (even if not certain) explanations for the making of the translation: first, the aforementioned hypothesis that it was motivated by the insufficient linguistic proficiency in Hebrew of the Jews attending the Synagogue in Alexandria; second, the tradition that it was the successor of Ptolemy I Soter (therefore Ptolemy II Philadelphus) who, around the year 270 BCE, decided to have the Torah translated into Greek, in order to enrich the collections of the Library. ${ }^{26}$ According to the same tradition, Demetrius of Phalerum, a former Athenian statesman, was assigned the role of supervising the task. ${ }^{27}$ It is not implausible that both reasons may have played a complementary role, and therefore that a practical need of the Jewish community had met the monarch's desire to improve the capacity of the Library (thus widening the access to a text to which part of his subjects attributed capital importance).

This tradition is, in fact, recorded in a document known as the Letter of Aristeas, supposedly written by a courtier, but whose author is most probably a Jew. According to this testimony, the Jewish community and the king himself were so satisfied with the work of the translators that they decided that it should be considered a paradigmatic text and remain unchanged in the future. For the purposes of this analysis, and despite the great importance of the exegetic questions raised by the Bible of the Septuagint, it is the reaction of the Jews and the way the Jewish community is represented that has a more direct interest. Let us evoke then a paraphrase of the Letter of Aristeas provided by Josephus ${ }^{28}$ :

\footnotetext{
Now, when the Law (nomos) had been transcribed and the work of translation brought to an end in seventy-two days, Demetrius assembled all the Jews at the same place where the laws (nomoi) had been rendered, and in the presence of the translators read them aloud. Thereupon the people expressed their approval of the elders who had interpreted the Law (nomos), and also praised Demetrius for conceiving the idea through which he had become the originator of great benefits to them, and they urged him as well to give their leaders the
}

26 See Feldman and Reinhold, Jewish Life and Thought among Greeks and Romans, 17-22, at $18-19$.

27 As is remarked by Mélèze Modrzejewski, The Jews of Egypt, 100, this attribution to Demetrius is rather awkward, because he "had been unwise enough to favor the succession of the king's eldest son in preference to Philadelphus," falling into disgrace when Philadelphus was made king."

28 Translation by Ralph Marcus, Flavius Josephus: Jewish Antiquities, Books XII-XIV (London: Loeb, 1957), 53-5. 
Law (nomos) to read; and all of them, including the priest and the eldest of the translators and the chief officers (proestekotes) of the community (politeuma), requested that, since the translation had been so successfully completed, it should remain as it was and not be altered. (Josephus, Ant. 12.107-108)

From a political and legal standpoint, this text provides some precious information. The juridical nature of the Torah is insistently underlined by the terms used to refer to it in Greek (nomos/nomoi); on the other side, the Jewish community is given the name politeuma. In the above-mentioned passage of Pseudo-Hecataeus on the coming of Ezekias to Alexandria (Josephus, Ag. Ap. 1.189), it was the word katoikesis that was used, a term that, together with the variant katoikia, is the one generally employed to define a colony of outsiders in a particular site. ${ }^{29}$ This kind of organization implied some capacity of self-government, but not necessarily the civic rights characteristic of a city. ${ }^{30}$ Politeuma is a word that may also be used to name generically any urban settlement and its inhabitants, although it classifies more in particular a community of alien settlers (even if not specifically Jews), with privileges up to a certain point comparable to civic rights. Another distinctive aspect that deserves being mentioned is that those ethnic groups are regularly characterized by a strong religious identity. As has been suggested, ${ }^{31}$ it seems persuasive that the Jewish politeuma of Alexandria was military in origin, and that this circumstance may have granted the members of the garrison a distinct and superior status by comparison to the rest of the Jewish community, which constituted the plethos of Alexandria in broad sense.

In order to establish politeumata and katoikiai it would certainly be necessary to have an official authorization. Maybe the above-mentioned politeia gegrammene in the passage of Pseudo-Hecataeus about Ezekias could have corresponded to this foundational document, despite the difficulties concerning the interpretation of this expression. On the other side, even if the tradition of the benefits granted by Alexander to the Jews is certainly magnified and at the very least in part anachronistic, it may nevertheless reflect the essence of the conditions given to the first Jewish settlers of Alexandria ${ }^{32}$ : the right of living according to their ancestral laws or customs (patrioi nomoi, idioi nomoi, ethe patria), and of applying those same

29 On the terminology used in the sources to refer to those relatively autonomous communities, see Hegermann, “The Diaspora in the Hellenistic Age,” 158-61.

30 Nevertheless, sometimes the politeumata could develop into cities. There were other designations to name communities of aliens, like laos, synodos and synagoge (although the latter two are later in time).

31 By Sandra Gambetti, The Alexandrian Riots of 38 C.E. and the Persecution of the Jews: A Historical Reconstruction (Leiden: Brill, 2009), 48-9.

32 See supra commentary on Josephus, Ant. 11.337-339. 
traditional laws among the persons who voluntarily consider them as binding rules - as long as they did not enter in conflict with the royal authority. The balance between sharing and hiding the force of a traditional religious identity was therefore essential to the success of this kind of social and political integration.

Even without including among those concessions the right of full citizenship (as happened with the Greek and Macedonian communities), this was undoubtedly an intelligent way of promoting mobility and attracting active populations. It also favoured social peace, because politeumata like the one that is believed to have existed in Alexandria had the legal capacity of appointing magistrates and of creating their own grid of courts and schools, where the norms of the Mosaic Law could be applied and taught. ${ }^{33}$ This reality is, in fact, clearly underlined by another passage in Josephus ${ }^{34}$ :

In Egypt, for example, territory has been set apart for a Jewish settlement (katoikia), and in Alexandria a great part of the city (polis) has been allocated to this nation (ethnos). And an ethnarch (ethnarches) of their own has been installed, who governs the people (ethnos) and adjudicates suits (kriseis) and supervises contracts (symbolaia) and ordinances (prostagmata), just as if he were the head (archon) of a sovereign state (politeia autoteles). (Josephus, $A J$ 14.117).

Apparently, the governing structure was initially almost monarchic, but maybe it did not last long, because the paraphrase of the Letter of Aristeas, previously discussed, refers to a group of "chief officers (proestekotes) of the community (politeuma)", and not to a single person who concentrated in himself all the authority. It is also not improbable that the governing structure of the politeuma may have suffered the effects of a growing Greek influence, as happened with the language and with some more practical procedures, like those involving for example Jewish litigants and Greek judges. ${ }^{35}$ In reality and albeit after having followed a very different path, the Greeks of Alexandria and of other Hellenistic

33 Hegermann, “The Diaspora in the Hellenistic Age," 161, accepts that some Jewish colonists may have acquired, as a personal reward, the status of full citizenship, but he maintains (as most scholars do) that the Jews as a community never obtained that right. In the future, this situation would be the cause of significant tensions with the Greek community, as happened when, by the time of Augustus, it was decided to apply taxes to all non-citizens, thereby reducing as well the rights of the Jewish politeuma of Alexandria. On this, see Nuno S. Rodrigues, Iudaei in Vrbe: Os Judeus em Roma de Pompeio aos Flávios (Lisbon: Calouste Gulbenkian, 2007), 337; Kasher, “The Jewish Politeuma in Alexandria,” 117-18.

34 Translation by Marcus, Flavius Josephus: Jewish Antiquities, Books XII-XIV, 509.

35 This is the situation of a certain Dositheos, a Jew of Egyptian origin, who had sued a Jewish woman; their case was judged by a group of Greek magistrates, in a court of Crocodilopolis. On this case, see Mélèze Modrzejewski, The Jews of Egypt, 108-9. 
cities had reached a set of regulations understood as "common laws" or "civic laws" (politikoi nomoi), which remitted not to an archetypical text (as happened with the Jewish Torah), but to a tradition common to several poleis, which formed a juridical structure globally identified with the Greek legal experience. The recognition of the binding validity of those traditional determinations (which fell into the broad concept of patrioi nomoi) ended up by being one of the most efficient solutions found by the Ptolemies to attract to Egypt many foreigners and to stimulate mobility without putting at risk social peace and the authority of the monarch. In effect, the several Egyptian, Greek and Jewish nomoi, to which legal validity was granted, had to be harmonized with the authority of the monarch, who had the ultimate word in the administration of justice, through his regulations and ordinances. But just as the politikoi nomoi provided the Greek community with the juridical framework necessary to the political organization and to the resolution of conflicts, the same could have been achieved through the Torah in what respects the Jewish politeuma.

As time went by and as a natural result of this confluence of multiple political traditions, the emergence of a common legal substrate should be expected, comparable in its origins and objectives to the process under way in other domains characteristic of this period. Thereby, just as it happened with the linguistic and cultural koine, the Hellenistic age (and especially Alexandria) must have favoured also the development of a legal koine, responsible as well for the success of the Ptolemies. ${ }^{36}$ Thus, they found an acute way of harmonizing the cosmopolitanism originated by the new political and social reality with the necessity to keep a strong identitarian matrix. And, at the same time, this balanced way of sharing and hiding the boundaries of a religious identity, a space for the affirmation of some degree of individuality, was safeguarded, in a universe marked by the confluence of multiple ethnic, political and religious sensibilities.

\section{References}

Arnaldo Biscardi, "Polis, politeia, politeuma," in Atti del XVII Congresso Internazionale di Papirologia (Naples: Centro Internazionale per lo Studio dei Papiri Ercolanesi, 1984), 1201-15.

Andrew Erskine, "Culture and Power in Ptolemaic Egypt: The Museum and Library of Alexandria," Greece and Rome 42 (1995): 38-48.

Louis H. Feldman and Meyer Reinhold, Jewish Life and Thought among Greeks and Romans: Primary Readings (Edinburgh: T\&T Clark, 1996).

36 On the characteristics of this legal koine, see Mélèze Modrzejewski, The Jews of Egypt, 107-12. 
Sandra Gambetti, The Alexandrian Riots of 38 C.E. and the Persecution of the Jews: a Historical Reconstruction (Leiden: Brill, 2009).

Mogens Herman Hansen, "Polis, Politeuma and Politeia: A Note on Arist. Pol. 1278b6-14," in From Political Architecture to Stephanus Byzantius: Sources for the Ancient Greek Polis, ed. David Whitehead (Stuttgart: Franz Steiner, 1994), 91-8.

Waldemar Heckel and John C. Yardley, Alexander the Great: Historical Sources in Translation (Malden: Blackwell, 2004).

Harald Hegermann, "The Diaspora in the Hellenistic Age," in The Cambridge History of Judaism, ed. William D. Davies and Louis Finkelstein (Cambridge: Cambridge University Press, 1989), 115-67.

Martin Hengel, "The Interpenetration of Judaism and Hellenism in the pre-Maccabean Period," in The Cambridge History of Judaism, ed. William D. Davies and Louis Finkelstein (Cambridge: Cambridge University Press, 1989).

Sylvie Honigman, The Septuagint and Homeric Scholarship in Alexandria: A Study in the Narrative of The Letter of Aristeas (London: Routledge, 2003),98 118.

Aryeh Kasher, "The Jewish Politeuma in Alexandria: A Pattern of Jewish Communal Life in the Greco-Roman Diaspora," in Homelands and Diasporas: Greeks, Jews and Their Migrations, ed. Minna Rozen (London: I.B. Tauris, 2008), 109-25.

Delfim F. Leão, “The Tyrannos as a Sophos in the Septem Sapientium Convivium", in Symposion and Philanthropia in Plutarch, ed. José Ribeiro Ferreira, Delfim Leão, Manuel Tröster, and Paula Barata Dias (Coimbra: Imprensa da Universidade, 2009), 511-21.

Delfim F. Leão, “Alexandre Magno: da estratégia pan-helénica ao cosmopolitismo," in Atti del convegno internazionale di studi "Plutarco e l'età ellenistica," ed. Angelo Casanova (Florence: Università degli Studi di Firenze, 2005), 23-37.

Delfim F. Leão, “Identity and Cosmopolitanism: The Jewish 'Politeuma' of Alexandria," in Alexandrea ad Aegyptum: The Legacy of Multiculturalism in Antiquity, ed. Rogério Sousa, Maria C. Fialho, Mona Haggag, and Nuno S. Rodrigues (Porto: Afrontamento, 2013), 122-33.

Delfim F. Leão, “Politeuma in Plutarch," Synthesis 23 (2016): e007. Released November 2016: http://www.synthesis.fahce.unlp.edu.ar/article/view/SYNe007.

Gert Lüderitz(1994), “What is the politeuma?” in Studies in Early Jewish Epigraphy, ed. Jan Willem van Henten and Pieter W. van der Horst, Arbeiten zur Geschichte des antiken Judentums und des Urchristentums 21 (Leiden: Brill, 1994), 183-225.

Ralph Marcus, Flavius Josephus: Jewish Antiquities, Books XII-XIV (London: Loeb, 1957) Ralph Marcus, Flavius Josephus. Jewish Antiquities, Books IX-XI (London: Loeb, 1958).

Steve Mason, Josephus. Against Apion: Translation and Commentary (Leiden: Brill, 2007). Joseph Mélèze Modrzejewski, The Jews of Egypt. From Rameses II to Emperor Hadrian (Skokie/ Ill.: Varda Books, 1995).

Victor Parker "Tyrannos. The Semantics of a Political Concept from Archilochus to Aristotle," Hermes 126 (1998): 145-72.

Nuno S. Rodrigues, "Um olhar a Oriente: Imagens do mundo semítico na literatura grega, dos Poemas Homéricos a Xenofonte," in Génese e consolidação da ideia de Europa. Vol. I: de Homero ao fim da Época Clássica, ed. Maria do Céu Fialho, Maria de Fátima Silva and Maria Helena da Rocha Pereira (Coimbra: Imprensa da Universidade, 2005), 335-65.

Nuno S. Rodrigues, Iudaei in Vrbe: Os Judeus em Roma de Pompeio aos Flávios (Lisbon: Calouste Gulbenkian, 2007).

Walter Ruppel (1927), “Politeuma: Bedeutungsgeschichte eines staatsrechtlichen Terminus," Philologus 82 (1927): 268-312 and 433-54. 
Patrick Sänger, "The Politeuma in the Hellenistic World (Third to First Century B.C.): A Form of Organisation to Integrate Minorities," in Migration und Integration - wissenschaftliche Perspektiven aus Österreich Jb 2, ed. Julia Dahlvik, Christoph Reinprecht, and Wiebke Sievers (Vienna: University Press, 2013), 51-68.

Patrick Sänger, "Die Jurisdiktion der jüdischen Gemeinde von Herakleopolis: Normal- oder Sonderfall im hellenistischen Ägypten?” in Symposion 2015: Vorträge zur griechischen und hellenistischen Rechtsgeschichte, ed. Delfim F. Leão and Gerhard Thür (Vienna: Verlag der Österreichischen Akademie der Wissenschaften, 2016), 213-32.

Patrick Sänger, "Das politeuma in der hellenistischen Staatenwelt: Eine Organisationsform zur Systemintegration von Minderheiten," in Minderheiten und Migration in dergriechisch-römischen Welt: politische, rechtliche, religiöse und kulturelle Aspekte, ed. Patrick Sänger, Studien zur historischen Migrationsforschung 31 (Paderborn: Ferdinand Schöningh, 2016), 25-45.

Constantine Zuckerman, "Hellenistic politeumata and the Jews: A Reconsideration," Scripta Classica Israelica 8/9 (1985-1988): 171-85. 